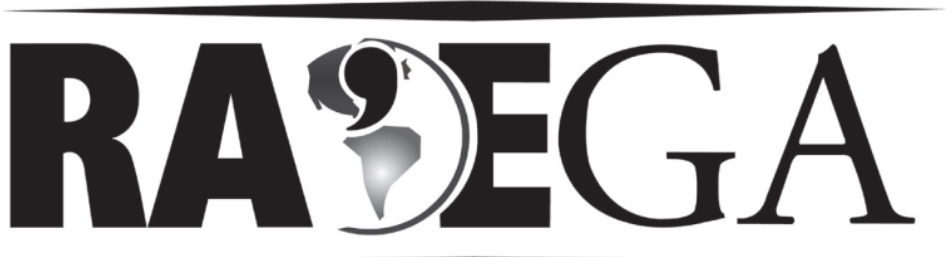

O ESPAÇO GEOGRÁFICO EM ANÁLISE

\title{
ANÁLISE ESPAÇO-TEMPORAL DA COBERTURA VEGETAL E DO AVANÇO DE Prosopis juliflora (SW) DC NUMA ÁREA DE CAATINGA
}

\section{ANALYSIS SPATIAL AND TEMPORAL OF VEGETATION COVER AND ADVANCE OF Prosopis juliflora (SW) DC IN CAATINGA AREA}

\author{
Ronildo Alcântara Pereira ${ }^{1}$ \\ Clênia Rodrigues Alcântara² \\ José Dantas Neto ${ }^{3}$ \\ Erivaldo Moreira Barbosa ${ }^{4}$
}

\section{RESUMO}

Um dos principais problemas existentes na Caatinga é a acentuada redução na cobertura vegetal, resultante das práticas ali realizadas e para as quais se atribui uma série de impactos no ambiente. Uma das soluções pensadas foi a introdução da Algaroba [Prosopis juliflora (SW) DC], que acabou por precipitar uma série de problemas. Assim, este trabalho objetivou analisar a cobertura vegetal e a expansão da Algaroba, bem como seus impactos em São João do Cariri-PB, em vinte anos. A análise via geoprocessamento demonstrou

\footnotetext{
${ }^{1}$ Geógrafo, Doutor pelo Programa de Pós-graduação em Recursos Naturais da Universidade Federal de Campina Grande - UFCG. Rua Aprígio Veloso, 882, Bodocongó, Bloco CL, CEP 58109-080. Campina Grande - PB, Brasil (ron_alcan@yahoo.com.br).

${ }^{2}$ Meteorologista, Doutora em Meteorologia pela Universidade de São Paulo - USP e Professora do Departamento de Ciências Atmosféricas - Universidade Federal de Campina Grande. Campina Grande PB, Brasil (clenia@gmail.com).

${ }^{3}$ Agrônomo, Doutor em Agronomia e professor do Programa de Pós-graduação em Recursos Naturais Universidade Federal de Campina Grande. Campina Grande - PB, Brasil (zedantas552gmail.com).

${ }^{4}$ Bacharel em Direito, Doutor em Recursos Naturais e professor do Programa de Pós-graduação em Recursos Naturais - Universidade Federal de Campina Grande. Campina Grande - PB, Brasil (erifat@terra.com.br).
} 
decréscimos na cobertura vegetal nativa e o crescimento significativo dessa espécie, apontando para a necessidade de maior conhecimento de técnicas de manejo capazes de oferecer condições para o aproveitamento do seu potencial.

Palavras-chave: Algaroba; Bioma Caatinga; Cobertura Vegetal; Sensoriamento Remoto.

\begin{abstract}
One of the main problems in the Caatinga biome is the marked reduction in vegetation cover resulting from the practices carried out there, which is assigned a series of environmental impacts. One of the thinked solutions was to introduce the Mesquite [Prosopis juliflora (SW) DC]. This precipitate a range of problems. Thus, this study aimed to examine the vegetation cover and the expansion of Mesquite, as well as their impacts in São João do Cariri City, within twenty years. The analysis via GIS showed decreases in native vegetation cover and significant growth of the species, pointing to the need for greater knowledge of management techniques that can offer the better conditions to use of potential of the Mesquite.
\end{abstract}

Keywords: Mesquite; Caatinga Biome; Vegetation Cover; Remote Sensing.

\title{
INTRODUÇÃO
}

Grande parte do Estado da Paraíba encontra-se sob os domínios da vegetação de Caatinga, que corresponde a uma área de mais de $900.000 \mathrm{Km}^{2}$, marcada pela concentração das precipitações em um curto período de tempo, quase sempre inferior a três meses do ano, estando os demais meses sob condições de elevado déficit hídrico e forte insolação. Frente a tais condições, fica fácil apontar as secas como a causa dos grandes problemas do Semiárido, embora hoje já se saiba que estas apenas agravam as sequelas ecossociais da região, haja vista a gama de aspectos que concorrem para cimentar o quadro socioambiental ali existente. Como forma de encontrar saídas para as questões dessa vasta área, agravada pelo fenômeno da estiagem, mas, principalmente, devido aos insucessos das políticas públicas para convivência com 0 fenômeno, o tema tem ocupado a pauta de discussão de pesquisadores e personalidades de destaque de diversos segmentos, há séculos (VILLA, 2000). 
Jofilly (1892) e Andrade (1986) já se referiam às secas do Nordeste como sendo uma das maiores chagas do país, para as quais não se assinalava, por parte das autoridades, interesse em enfrentá-las. Segundo Jofilly (op. cit.), mais que boa vontade, sempre faltou interesse político para a resolução da problemática. Seu ponto de vista era o de que "o homem não tem controle sobre os elementos climáticos que produzem as secas, mas pode, até certo ponto, diminuir os seus inconvenientes e, até mesmo, eliminá-los num determinado território, por uma gama considerável de ações".

Entretanto, embora o tema venha sendo discutido exaustivamente e muitas ações terem sido implementadas, o grosso delas não alcançou o êxito desejado, visto que, na maioria das vezes, foram pautadas na importação de modelos, tecnologias ou insumos que, posteriormente, se mostraram inadequados (ANDRADE et al., 2006). A esse respeito, Ab Saber (2003) aponta que uma parcela considerável da sociedade nordestina acostumou-se a ver impingido à região, programas e planos tecnocráticos, genéricos e prejudiciais elaborados em relatórios de baixo nível de abrangência científica e avaliação crítica, suscitando uma natural propensão para fundadas desconfianças.

Neste sentido, as estratégias, adotadas pelo poder público para atenuar as distorções regionais e tentar aproximar as condições de vida do Semiárido às outras regiões brasileiras, somam cada vez mais insucessos e se tornam ainda mais graves quando as mesmas são desprovidas de qualquer embasamento técnico. A introdução da espécie exótica Algaroba [Prosopis juliflora (SW) DC] no Semiárido parece um exemplo bem sugestivo, sobretudo quando aplicado em um reduto de biodiversidade frágil, como é o caso da Caatinga. Esta espécie foi introduzida na região Nordeste nos anos 1940, porém sem grande destaque. No entanto, na década 1970, o governo federal propôs um projeto no qual substituía a vegetação original da Caatinga pela Algaroba (Duarte, 2000).

Nascimento (2008), tendo como base diversos autores, comenta que a invasão biológica fica caracterizada quando um organismo ocupa um espaço 
fora de sua área de dispersão geográfica, com adaptação da espécie, alterando o ecossistema, com alterações sensíveis ao meio.

Para ser qualificada como exótica, os estudiosos apresentam algumas razões. Vilar (2006) explica que se trata de um organismo que coloniza comunidades autóctones, adaptando-se e reproduzindo-se, passando a competir biologicamente com as espécies nativas, provocando alterações nos processos ecológicos naturais e, por fim, tornando-se muitas vezes dominantes nesses ambientes.

O processo de invasão de um ecossistema por uma espécie exótica se dá quando a mesma se adapta, passando a se dispersar e a alterar o ambiente em seu entorno. Na Caatinga, a introdução da Algaroba, trazida com o objetivo de constituir uma alternativa econômica para a região, resultou em uma invasão (ANDRADE et al., 2005; TELES et al., 2006; OLIVEIRA, 2006).

Conforme explica Oliveira (2006), ações desse porte fomentam a histórica pressão antrópica exercida sobre a Caatinga, somada às características naturais, concorrendo para acentuar a degradação do meio físico, com consequências danosas para a sua biodiversidade. Tanto é assim, que, na Caatinga, já são raríssimos os remanescentes de mata nativa em bom estado de conservação. Além disso, uma vez que a algaroba se desenvolve sem qualquer controle, gera diversos malefícios nas atividades produtivas, 0 que acaba por aumentar as vulnerabilidades ambientais da região Semiárida (PEREIRA, 2008).

Outro problema inerente à aludida espécie é apontado por Vilar (2006), para quem a Algaroba, além de competir com a Caatinga arbórea, também disputa espaço com a vegetação arbustiva e herbácea. Note-se tal aspecto como de vital importância, porque é no extrato herbáceo que os animais silvestres e domésticos encontram alimento, além do que é ali que são encontradas muitas das ervas medicinais, utilizadas pelas comunidades locais. Somado a tudo isso, os sítios preferenciais da citada espécie constituem áreas de relevante interesse social e ambiental para a Caatinga, isto porque ocupa, principalmente, os Neossolos Fúlvicos e as manchas de solos mais profundas, locais onde a água é mais facilmente encontrada (ANDRADE et al., 2005). 
Lins e Silva (1997), no primeiro estudo sobre a invasão da Algaroba no Nordeste Brasileiro, constataram, no avanço das populações dessa espécie, algumas particularidades, descrevendo-as como invasoras das áreas da caatinga e evidenciando o processo de disseminação, sendo especialmente as perturbações e a proximidade de água as responsáveis por seu sucesso hostil.

Em face do problema mencionado, a presente pesquisa objetivou analisar a evolução, no período de vinte anos, do nível de cobertura vegetal, do uso e ocupação do solo do município de São João do Cariri - PB e identificar as áreas de inserção e a dinâmica ambiental local ocasionada pela Algaroba [Prosopis juliflora (SW) DC], apontando alguns dos seus impactos sobre o meio ambiente.

\section{MATERIAL E MÉTODOS}

\section{Material}

O material utilizado nesta pesquisa constituiu-se de dados orbitais e planialtimétricos, que alimentaram o sistema de informação geográfica (SIG), por meio do software SPRING 4.3.3, disponibilizado livremente pelo Instituto Nacional de Pesquisas Espaciais (INPE). Para complementar as análises foi utilizado equipamento de sistema de posicionamento global (GPS) para localização das coordenadas geográficas de interesse desse estudo e máquina fotográfica para registro dos impactos pontuais identificados.

Os dados orbitais e planialtimétricos utilizados foram os seguintes: a) imagens dos satélites TM/LANDSAT-5 e CCD/CBERS-2, disponibilizadas pelo INPE, referentes aos anos de 1987, 1996 e 2007, das quais foram extraídas as informações mediante várias etapas do processamento; b) produtos cartográficos, compostos por cartas planialtimétricas da SUDENE (1972) na escala 1:100.000 correspondente à área dos municípios: Juazeirinho [0704'01"S; 36³4'42”W] (SB.24-Z-D-II); Boqueirão [07²8'49”S; 3608'02”W] (SB.24-Z-D-III) e Sumé [07040'17”S; 3652'54”W] (SB.24-Z-D-V), as quais deram o suporte para o georreferenciamento das imagens de satélite. 
As imagens selecionadas correspondem às datas de passagens dos satélites nos dias 09/05/1987, 22/07/1996 e 04/06/2007. A escolha das cenas desse período foi objeto de especial atenção, haja vista a necessidade de se comparar o estado da cobertura vegetal em vários anos, levando-se em conta as mesmas condições. Para isso, adotou-se o período que compreende a quadra chuvosa, em que, a priori, o índice folhear encontrava-se em seu ápice, fato que favoreceu a formulação de uma resposta espectral a esse alvo, a ponto de permitir uma melhor comparação na evolução da dinâmica do processo de cobertura dos diferentes anos estudados.

Se por um lado o índice foliar do período chuvoso favorece a comparação dos diferentes anos estudados, por outro, nesta época do ano, a cobertura de nuvens dificulta sobremaneira a aquisição de produtos oriundos de satélite forçando, muitas vezes, ao uso de imagens com cobertura de nuvens acima do aceitável.

Outros dados complementares, como a determinação de coordenadas, identificação de impactos pontuais e feições fisiográficas da vegetação em nível de detalhe, foram obtidos através de trabalho de campo. De acordo com Anjos e Venezianni (1982), este procedimento não deve ser relegado sob nenhuma hipótese, pois tem a finalidade de conhecer os aspectos relativos da área de estudo, como forma de diagnóstico auxiliar, e dirimir dúvidas que surgem por ocasião das operações de manipulação das imagens. Dessa forma, várias visitas à área de estudo foram realizadas entre os meses de janeiro e setembro de 2008.

Por fim, foram utilizados dados de precipitação de três localidades limítrofes ao município de São João do Cariri: Cabaceiras (7030'S; 36 $\left.17^{\circ} \mathrm{W}\right)$,

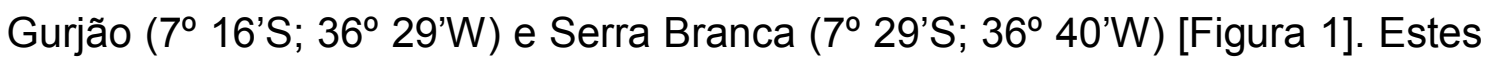
municípios foram escolhidos por conterem séries de dados sem falhas, bem como por estarem inseridos na problemática aqui discutida e apresentarem características climáticas semelhantes ao município em estudo. Os dados são médias mensais de precipitação do período entre os anos de 1962 a 2010, totalizando 48 anos de informações. Além de auxiliar nas análises derivadas das imagens de satélite, com eles foi possível entender um pouco das 
características climatológicas da área em estudo. Esses dados foram cedidos pelo Departamento de Ciências Atmosféricas da Universidade Federal de Campina Grande (UFCG).

\section{Área de estudo}

A extensão territorial do município de São João do Cariri, localizado na parte central do Estado da Paraíba, na microrregião do Cariri Oriental e inserido na Mesorregião da Borborema é de $700,6 \mathrm{Km}^{2}$, representando 1,24\% da área do Estado (Figura 1). A sede municipal localiza-se entre as coordenadas (“07 23' 27" S; "36 31' 58” W), distante 217 Km de João Pessoa, capital do Estado da Paraíba e tem como vias de ligação as rodovias BR 230 e 412 (IBGE, 2006).

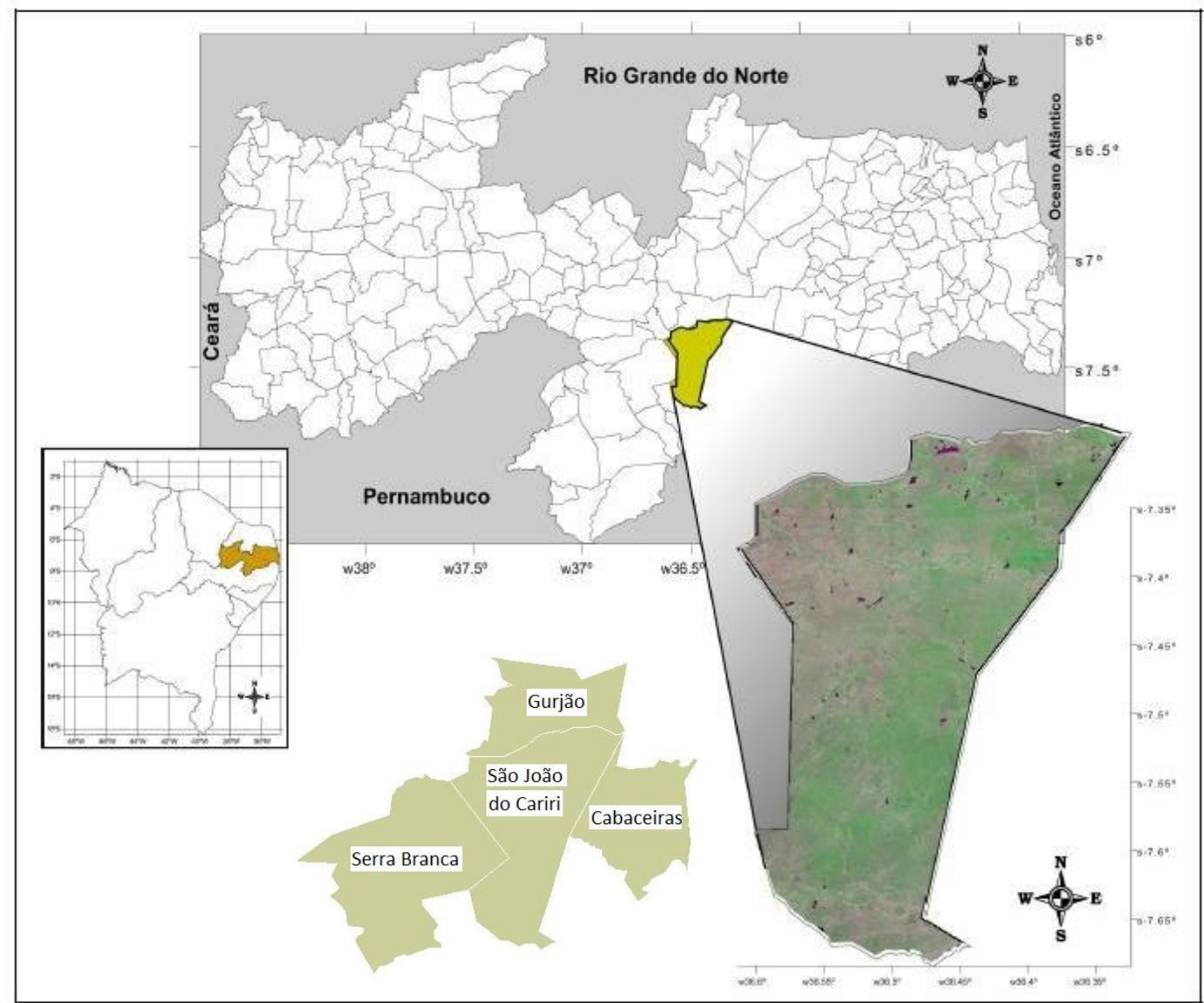

Figura 1. Localização geográfica do município de São João do Cariri-PB. Abaixo, detalhe dos municípios vizinhos: Cabaceiras, Gurjão e Serra Branca. Fonte: Pereira et al., (2009). 
O clima em São João do Cariri é quente e úmido, classificado por Köppen como Bsh e caracterizado por uma baixa e irregular pluviosidade, concentrada em apenas três meses do ano, na faixa compreendida entre $300 \mathrm{e}$ $900 \mathrm{~mm} / \mathrm{ano}$. As temperaturas médias anuais são da ordem de 26 a $29^{\circ} \mathrm{C}$. $\mathrm{O}$ quadro climático descrito gera uma umidade relativa do ar que apresenta médias anuais por volta de $50 \%$ e insolação que chega ao patamar de 2.800/h/ano, marcado pela predominância de uma cobertura vegetal constituída de espécies decíduas e caducifólias, com forte presença de cactáceas (AB SABER, 1974; MELO; RODRIGUEZ, 2004).

A precipitação no Semiárido está diretamente relacionada com a convecção local. Essa convecção é controlada pela circulação geral da atmosfera e por fenômenos de escala global. Segundo Molion e Oliveira (2002), os mecanismos dinâmicos que produzem chuva podem ser classificados em mecanismos de grande escala, que são responsáveis por cerca de $30 \%$ a $80 \%$ da precipitação, e meso e micro escala que completam os totais. Dos mecanismos de grande escala, destacam-se os sistemas frontais, atuantes ao sul da área, a Zona de Convergência Intertropical mais ao norte (UVO et al., 1988), e os Vórtices ciclônicos de altos níveis (GAN, 1983). Em meso escala, ondas de leste (YAMAZAKI; RAO, 1977), complexos convectivos e circulações do tipo brisa (KOUSKY, 1980). E em micro escala, circulações orográficas e pequenas células convectivas.

Em escala global, o El Niño - Oscilação Sul (ENOS) afeta muito a distribuição espacial e temporal das chuvas no Semiárido brasileiro. Isso porque altera os padrões da circulação atmosférica, deslocando o ramo descendente da célula de Walker para a região, inibindo a formação de nuvens produtoras de chuva. Dessa forma, em anos caracterizados pela fase negativa do ENOS (EI Niño), observa-se a ocorrência de eventos extremos de baixa precipitação, chamados secas, e em anos de fase positiva (La Niña), a precipitação tende a ser acima da normal climatológica (KOUSKY; CAVALCANTI, 1988). 
Outro condicionante de papel relevante é o elevado déficit hídrico que, segundo Rebouças (2001), chega a atingir $2.200 \mathrm{~mm} / \mathrm{ano}$, inviabilizando algumas técnicas de armazenamento de água, fato que torna ainda mais frágil as condições de vida local. Ainda sobre as feições climáticas, Teles et al., (2006) afirmam que um elemento associado à escassez de chuvas importante na definição do quadro climático da área é a irregularidade das precipitações, dentre as quais se destaca o período de janeiro a abril como o mais frequentemente chuvoso. Essas informações podem ser visualizadas na Figura 2, que mostra as precipitações médias mensais (a) e acumuladas anuais (b) para Cabaceiras, Gurjão e Serra Branca. Para essas localidades, os meses de maiores valores médios nos 48 anos de estudo são: fevereiro, março e abril.

A série completa pode ser vista na Figura $2 \mathrm{~b}$ com destaque para os anos 1987, 1996 e 2007, nos quais foram feitas as análises da cobertura vegetal. Percebe-se que os três municípios possuem tendências semelhantes de precipitação ao longo do período. Dos três anos, 1996 foi o que apresentou maior valor acumulado e 1987 foi o ano com menos precipitação observada.

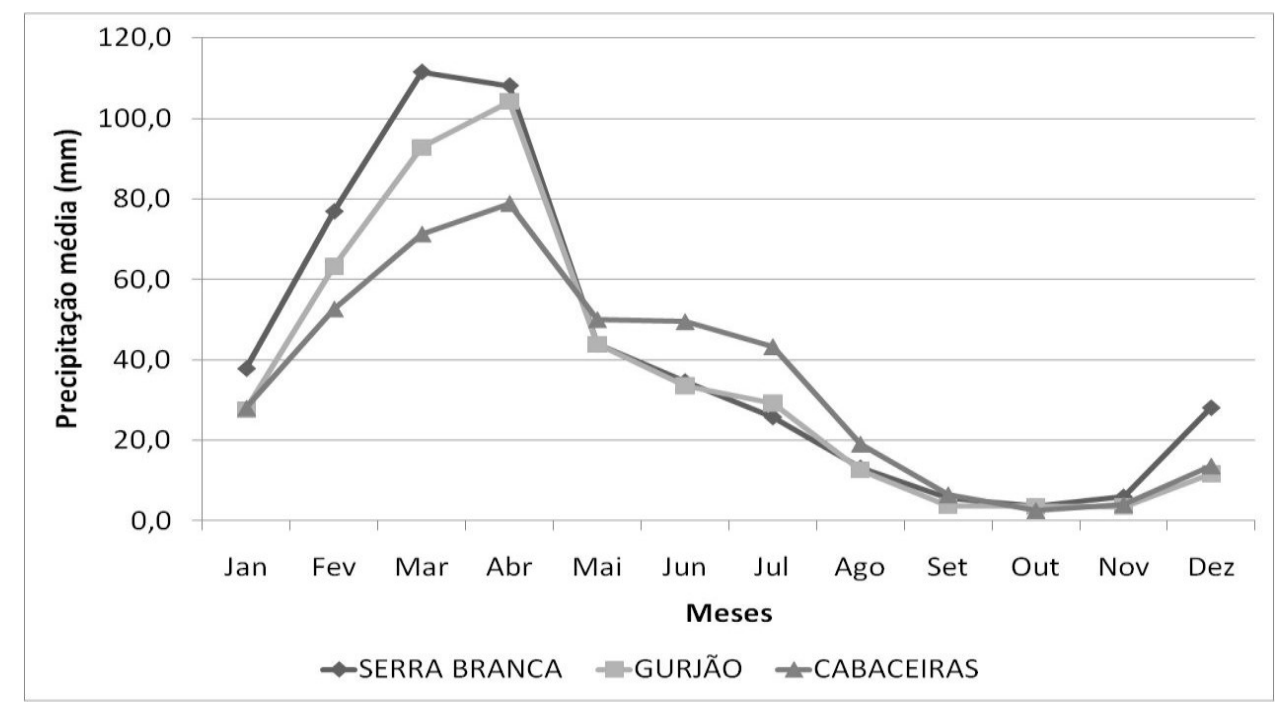

(a) 


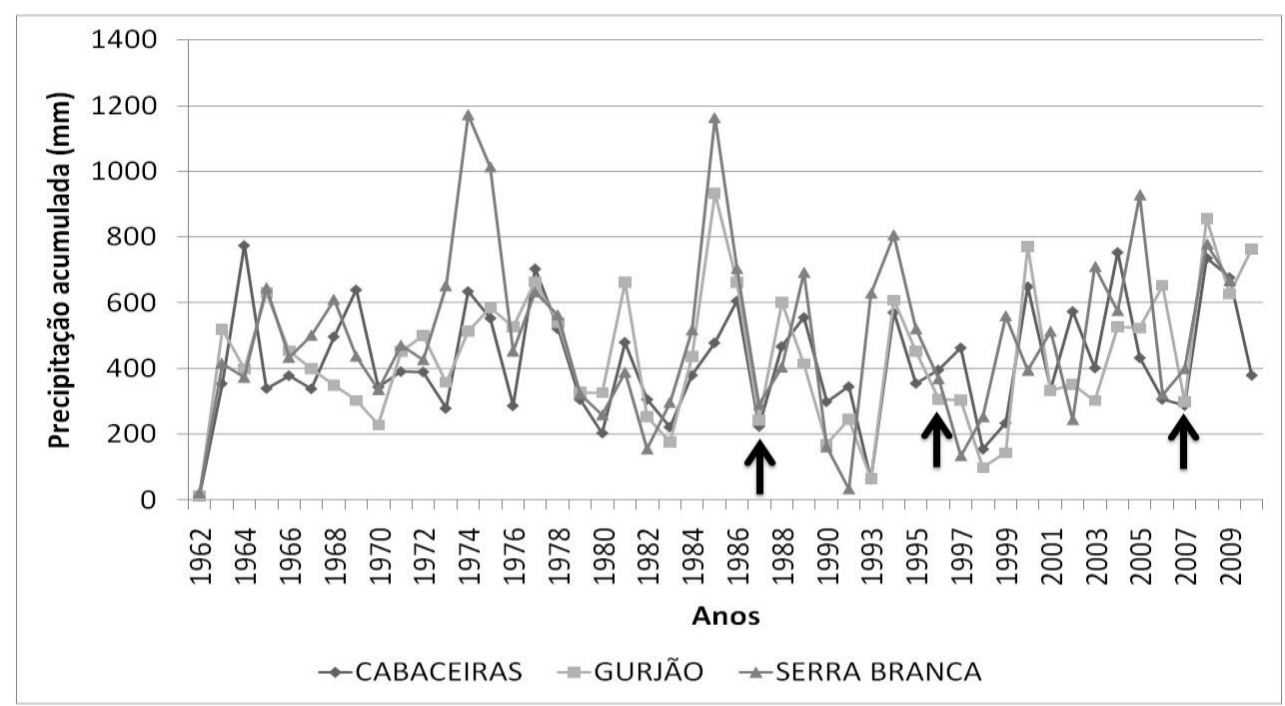

(b)

Figura 2. Precipitação média mensal (a) e acumulada anual (b) entre 1962 e 2010 para os municípios de Cabaceiras, Gurjão e Serra Branca. As setas indicam os anos de 1987, 1996 e 2007.

A tabela 1 sintetiza essas informações, pois mostra os valores acumulados de precipitação nos três anos mencionados, as médias climatológicas de 48 anos de dados e seus desvios-padrão. A irregularidade das precipitações citada em Teles et al., (2006) é demonstrada pelos altos valores do desvio-padrão, variando em torno de $200 \mathrm{~mm}$. Também se pode perceber que 1987 e 2007 tiveram precipitação abaixo da média e 1996 tendeu a ter valor em torno da média. Uma possível explicação para o comportamento da precipitação nesses anos pode estar na evolução do ENOS, já que em 1987 observou-se um evento moderado de El Niño, em 1996 estava estabelecido um evento fraco de La Niña e em 2007, El Niño fraco (Fonte: CPTEC/ INPE). 
Tabela 1. Médias e desvios-padrão de precipitação nos 48 anos de estudo e precipitação acumulada em 1987, 1996 e 2007 para Cabaceiras, Gurjão e Serra Branca.

\begin{tabular}{c|ccc}
\hline $\begin{array}{c}\text { Precipitação } \\
(\mathbf{m m})\end{array}$ & Cabaceiras & Gurjão & Serra Branca \\
\hline Média & 418,6 & 434,8 & 496,5 \\
Desvio-padrão & 176,2 & 206,4 & 257,2 \\
1987 & 223,6 & 242,0 & 290,0 \\
1996 & 396,1 & 307,0 & 520,3 \\
2007 & 288,1 & 298,1 & 320,9 \\
\hline
\end{tabular}

De acordo com IBGE (2008), o município de São João do Cariri tem como característica econômica a produção agropecuária, centrada principalmente na criação de bovinos e caprinos. Em tempos pretéritos, as atividades produtivas tinham como destaques a exploração de culturas industriais como o sisal e o algodão, hoje em declínio.

A produção de alimentos, atualmente, ainda ocorre de forma extensiva, por intermédio de culturas itinerantes e de forma mais ou menos permanente nos setores mais úmidos, representadas pelas áreas de climas amenos, várzeas e vazantes, além de perímetros irrigados, onde se destacam as culturas do milho e feijão (PEREIRA, 2008).

Quanto à estrutura fundiária, os estabelecimentos de menos de 50 ha faixa na qual se concentra a maioria dos produtores familiares - correspondem a $80 \%$ do total de estabelecimentos, mas ocupam apenas $15 \%$ da área total, o que demonstra que ainda há problemas na distribuição e posse das terras (BRASIL, 2005). No que refere à estrutura demográfica, de acordo com os resultados do censo realizado em 2010, São João do Cariri detém uma população de 4344 habitantes, apresentando densidade demográfica de 6,20 hab./ $\mathrm{Km}^{2}$, dos quais $54,03 \%$ é população urbana e $45,97 \%$ população rural (IBGE, 2011). 
Parcela significativa dessa população vive da renda de pequenas propriedades, por meio da agricultura de sequeiro e quando ocorrem períodos estios comercializam os subprodutos de origem vegetal como meio de sobrevivência das famílias (TELES et al., 2006). Na falta de vegetação nativa, a algaroba serve perfeitamente a tal propósito, uma vez que é uma ótima forrageira e apresenta qualidades como biomassa, tanto para queima, quanto para utilização em cercas. Além disso, como sua proliferação é de fácil disseminação, sua poda ou até mesmo a erradicação de parte de sua população ajuda a controlar as áreas por ela povoadas, favorecendo o crescimento da flora autóctone nestes espaços (ANDRADE et al., 2006).

\section{Processamento digital das imagens}

Os procedimentos para a interpretação visual de imagens digitais foram realizados tomando-se como parâmetros os elementos texturais do relevo, drenagem e outros alvos, segundo sua densidade e orientação (tropia), conforme prescrição metodológica preconizada por Anjos e Venezianni (1982).

Tal metodologia de análise das imagens consiste em uma sequência de etapas lógicas e sistemáticas que independem do conhecimento prévio da área e da utilização dos processos fotointerpretativos. Entretanto, tal método pode ser enriquecido com o aporte de dados auxiliares, colhidos por ocasião dos trabalhos de campo (ANJOS e VENEZIANNI, 1982).

Foram aplicados às imagens os seguintes procedimentos:

a) Técnicas de realce, que manipulam os contrastes de forma a melhorar a qualidade das imagens sob os critérios subjetivos do olho humano, sendo normalmente utilizadas como uma etapa de pré-processamento para sistemas de reconhecimento de padrões adotados;

b) Emprego do índice de vegetação NDVI (Normalized Difference Vegetation Index), expresso pela equação:

$$
N D V I=\text { ganho*}[(b 4-b 3) /(b 4+b 3)]+\text { offset }
$$


c) Composição multiespectral ajustada (b3 + NDVI + b1). Este procedimento diz respeito a uma transformação $R G B$, em que a luz vermelha incide na banda 3 , a luz verde na imagem NDVI e a luz azul na banda 1 .

d) Segmentação, que se constitui de um agrupamento de pixels análogos, ainda que estes não sejam contíguos. Este processo rotula cada "pixel" como uma região distinta. O software calcula um critério de similaridade para cada par de regiões espacialmente adjacentes. O critério de similaridade baseia-se em um teste de hipótese estatístico que testa a média entre as regiões. A seguir, divide-se a imagem em um conjunto de sub-imagens e, então, realizase a união entre elas, segundo um limiar de agregação definido.

e) Classificação não supervisionada, que consiste no estabelecimento de um processo de decisão no qual um grupo de pixels é definido como pertencente a uma determinada classe, sem que o usuário tenha conhecimento do número ou identificação das diferentes classes presentes na imagem. Esse procedimento é realizado por meio do algoritmo de agrupamento e constituído pelas fases de treinamento, conforme o classificador Bhattacharrya que faz uso de amostras para estimar a função densidade de probabilidade para as classes determinadas, que, neste caso, definiu seis classes de cobertura da vegetação (vegetação densa, semidensa, rala, solo exposto, algaroba e água). No caso presente, foi usado o método de extração de regiões, com um limiar de 99,9\% de aceitação. Ao final, todas as regiões ficam associadas a uma classe definida pelo algoritmo, devendo o usuário associar essas classes ou temas às classes por ele definidas no banco de dados;

f) Vetorização das imagens classificadas;

g) Editoração dos mapas temáticos. Os mapas temáticos finais das classes de cobertura vegetal, da dinâmica de utilização das terras e dos níveis de degradação foram criados no módulo SCARTA, software complementar do SPRING, na versão 4.3.3. 


\section{RESULTADOS E DISCUSSÃO}

\section{Composições Multiespectrais Ajustadas (CMAS)}

Levando-se em conta a variabilidade da cobertura vegetal do município em análise, composta por diversas geofáceis morfológicas, decorrentes, principalmente, das condições climáticas ali presentes, a fisionomia da paisagem da área se modifica radicalmente ao longo do ano entre os períodos seco e chuvoso. Assim, o dinâmico espaço-temporal da redução ou recuperação da cobertura vegetal das terras do município foi analisado, como também, 2007 (Figuras, 3, 4 e 5 respectivamente).

Pode-se observar que as áreas com baixos índices de vegetação, ou seja, com solos expostos e vegetações ralas estão identificadas pelas cores margenta e amarela. Já as áreas, onde predomina a vegetação mais exuberante (maior nível de densidade vegetacional, ou seja, vegetação nativa), apresentam tom verde escuro. A tonalidade verde claro define as regiões onde a vegetação se encontra menos conservada e com algum estresse hídrico. Por fim, as áreas em branco representam degradações em níveis mais graves e/ou com déficit hídrico acentuado.

Partindo-se desse padrão de comparação entre composições multiespectrais, foi possível identificar a evolução do comportamento da cobertura vegetal. Os resultados indicaram uma evolução do processo de perda da vegetação nativa em diversos pontos do município, principalmente, nas áreas de maior concentração populacional (antropização), fato que justificaria a inserção da planta invasora, como forma de suprir a falta da vegetação nativa, em franco declínio, em face da exploração desordenada. No entanto, um aspecto não foi considerado: a ocupação pela população da Algaroba nas áreas de solos férteis às margens dos rios, lócus da produção de alimentos nesta área. 


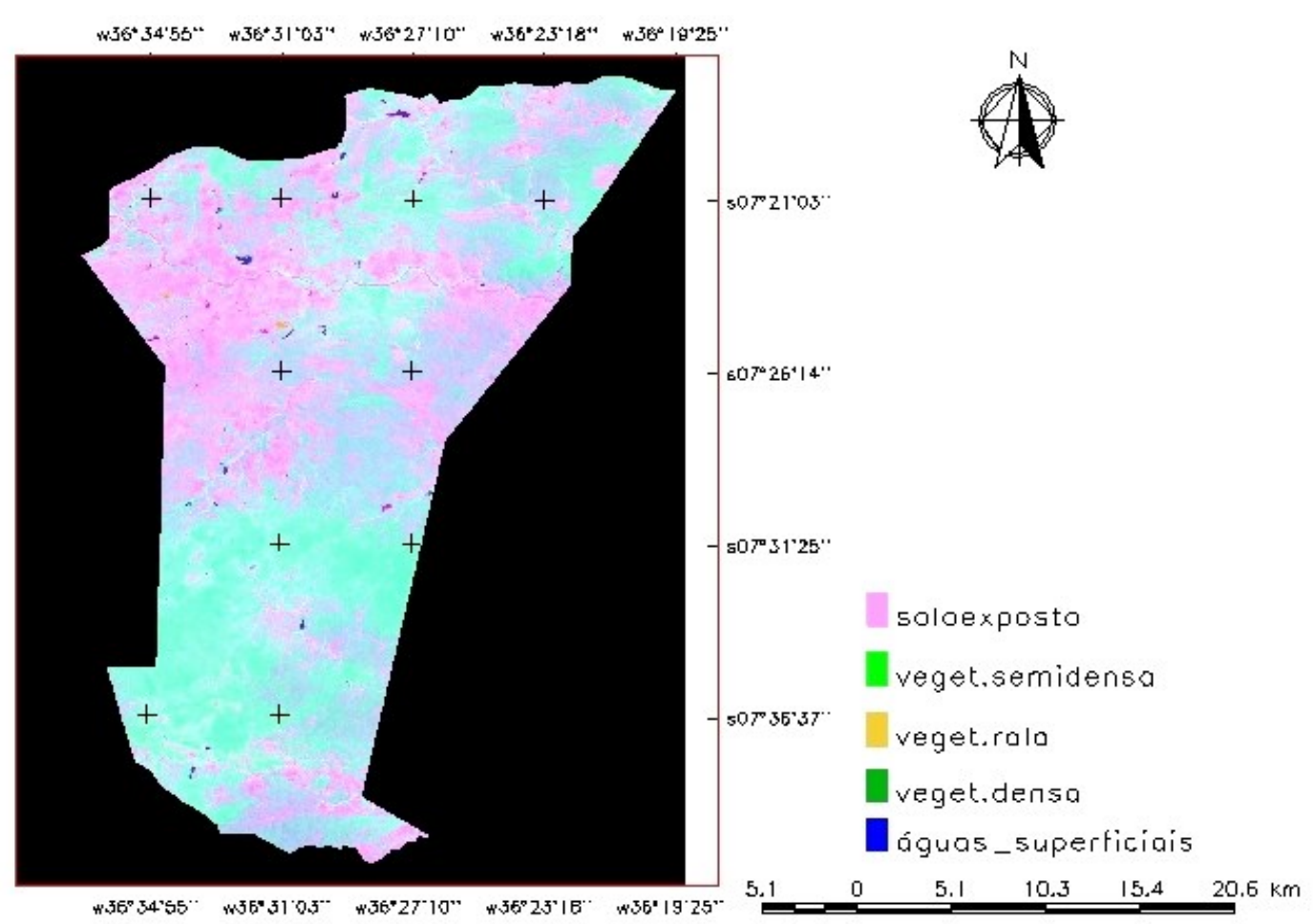

Figura 3. Composição multiespectral ajustada para análise das classes de vegetação de São João do Cariri, obtida mediante processamento da imagem Landsat 5, do sensor TM, oriunda do imageamento da data de passagem 09/05/1987, órbita 215, ponto 65.

A infestação ficou evidente quando foi observada no trabalho de campo a expansão da espécie exótica nas áreas de plantio próximo às margens dos rios, como será demonstrada adiante, mediante um aumento substancial da densidade vegetal. Esse problema que representa prejuízo à produção já foi objeto de estudo de alguns pesquisadores como Andrade et al. (2005), Andrade et al. (2006), além de outros já mencionados, os quais afirmam que a espécie traz desvantagens, tanto econômicas quanto biológicas, devido ao modo como se prolifera no ambiente, fato que, como já prenunciado, deprecia inclusive a flora nativa.

Em decorrência, surge outro fator de extrema gravidade, que é a perda de solo que, se não bastassem os prejuízos acarretados ao setor agrícola com a redução das áreas de plantio, ainda causa impactos aos corpos e cursos d'água através do processo de assoreamento. 


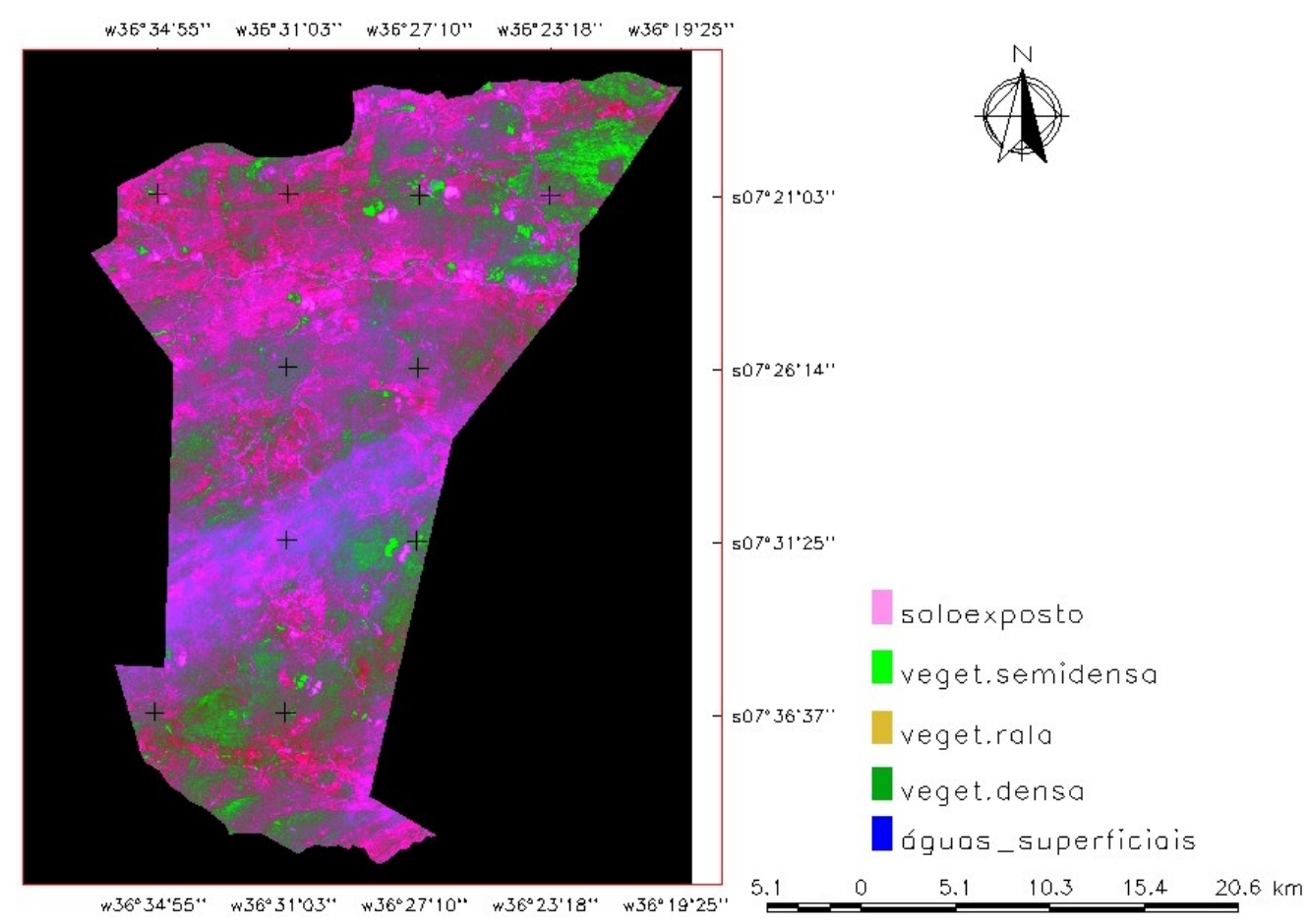

Figura 4. Composição multiespectral ajustada para análise das classes de vegetação de São João do Cariri, obtida por intermédio do processamento da imagem Landsat 5, do sensor TM, oriunda do imageamento da data de passagem 22/07/1996 órbita 215, ponto 65.

No que concerne ao processo de perda da vegetação, este se mostrou mais evidente, comparou-se às CMAS dos anos de 1987 e 1996. Em 1996, a quantidade de chuvas foi menor, fato atribuído ao evento El Niño moderado e que contribuiu para o agravamento da situação de sobrevivência na área. Devido à seca, foi observado o drástico agravamento das condições econômicas da população que usou mais intensamente os recursos florestais, tanto para conseguir recursos econômicos, como também para a alimentação dos rebanhos, por meio da queimada de cactos.

O quadro acima mencionado foi ratificado pelo trabalho de campo e confirmado pelos dados obtidos com a classificação das imagens mostradas na sequência deste estudo (PEREIRA et al., 2009). Todavia, na análise da composição multiespectral ajustada para o ano de 2007 (Figura 3), pode-se 
constatar uma sensível recuperação das áreas cobertas com vegetação densa, fato que sinalizou uma substancial melhora no total de áreas verde no município, demonstrando que a abundância de chuvas verificada no último decênio do estudo proporcionou, a despeito de todas as pressões sobre os recursos vegetacionais, a sua recuperação em um curto espaço de tempo.
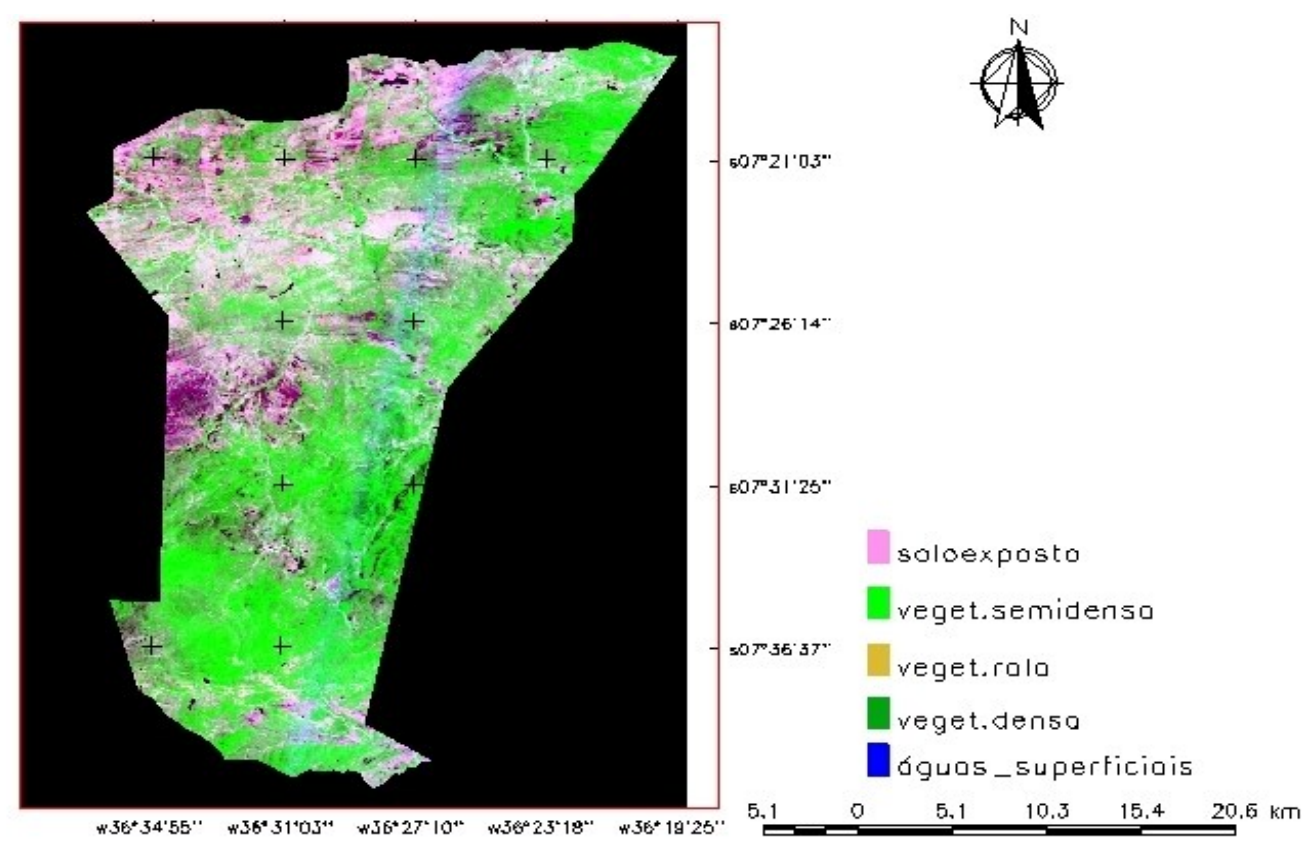

Figura 5. Composição multiespectral ajustada para análise das classes de vegetação de São João do Cariri do Cariri, obtida por meio do processamento da imagem CBRS, do sensor CCD, oriunda do imageamento da data de passagem 19/07/2007 órbita 215, ponto 65.

\section{Classificação e mapas das classes de cobertura vegetal}

A classificação dos padrões, cujos parâmetros se encontram na Tabela 2, seguiu as seguintes etapas: (i) segmentação (por extração de regiões); (ii) classificação não-supervisionada; (iii) mapeamento de classes temáticas; e (iv) vetorização dos dados. Depois de quantificadas as áreas, os resultados foram exportados para o SCARTA, possibilitando a editoração e confecção dos mapas digitais temáticos. 
Tabela 2. Parâmetros utilizados para a classificação de padrões das imagens TM/LANDSAT e CCD/CBERS.

\begin{tabular}{c|cc}
\hline NDVI & Ganho $=200$ & Offset $=100$ \\
\hline Segmentação & Similaridade 15 & Área pixel 20 \\
Classificação & Classificador: Bhattacharrya & Limiar de aceitação $=99.9$ \\
\hline
\end{tabular}

Os resultados obtidos pela classificação (Figuras 6, 7 e 8), indicou que, nos primeiros dez anos do período estudado, ocorreu uma drástica redução nas classes: vegetação densa e semidensa, as quais representavam $8,6 \%$ e $33,5 \%$ da área total do município em 1987, reduzindo-se para 6,1\% e 28,5\%, respectivamente, em 1996. Situação oposta verificou-se com as áreas correspondentes à classe vegetação rala, que em 1987 representava 30,7\% da área e se expandiu para 41,9\%. A classe solo exposto aumentou de 17,1\% para $18,9 \%$, conforme a Tabela 3 . Esse quadro mostra de forma inconteste que a estiagem não é apenas um fenômeno de impacto social, mas suas consequências recaem fortemente sobre o meio ambiente semiárido, e a dinâmica da vegetação reflete este processo.

A classe representada pela Algaroba (Prosopis juliflora), localizada, principalmente às margens dos rios e identificada pelo trabalho de campo, começou a surgir com maior força no período que compreende a primeira década correspondente ao estudo, embora também tenha sofrido um decréscimo de $7,5 \%$ para pouco mais de $6,9 \%$, em virtude do incremento da demanda sobre o setor vegetal, resultante do agravamento das condições socioeconômicas da população, ocasionado pela seca entre os anos de 1990 e 1993, decorrente de um evento de El Niño, classificado como forte (FONTE: CPTEC/INPE). 


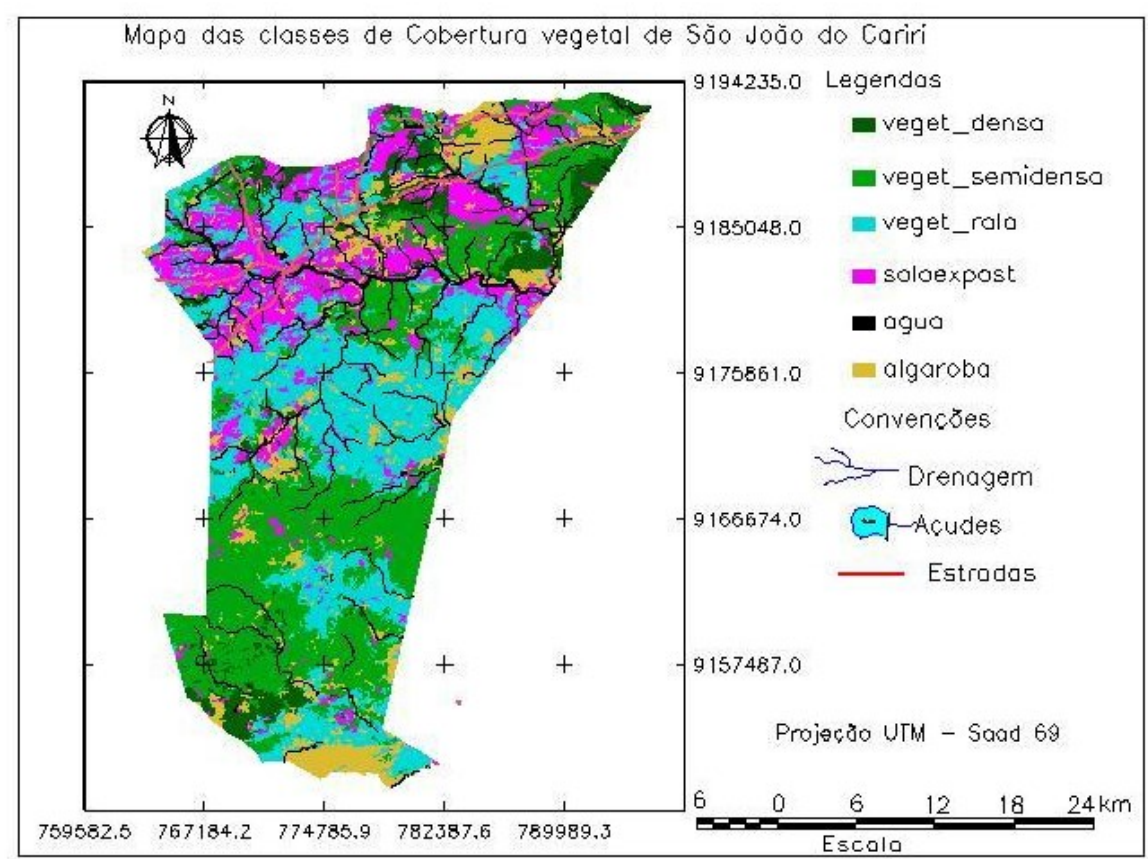

Figura 6. Mapa das classes da cobertura vegetal do ano de 1987 para São João do Cariri - PB, obtidas a partir das imagens CBRS, cartas cartográficas e trabalho de campo.

Numa análise mais setorizada dos mapas, pode-se observar que as áreas próximas aos rios, apresentadas na cor margenta, mostram-se mais degradas em todo o período estudado, em função da concentração das atividades produtivas. A única cobertura vegetal ali existente é a Algaroba, mostrada em amarelo, fato confirmado pelo trabalho de campo. Nas áreas centro-sul do município, apresentadas ciano, há uma forte predominância da cobertura vegetal rala (arbustiva), denunciado o predomínio da atividade pastoril. 


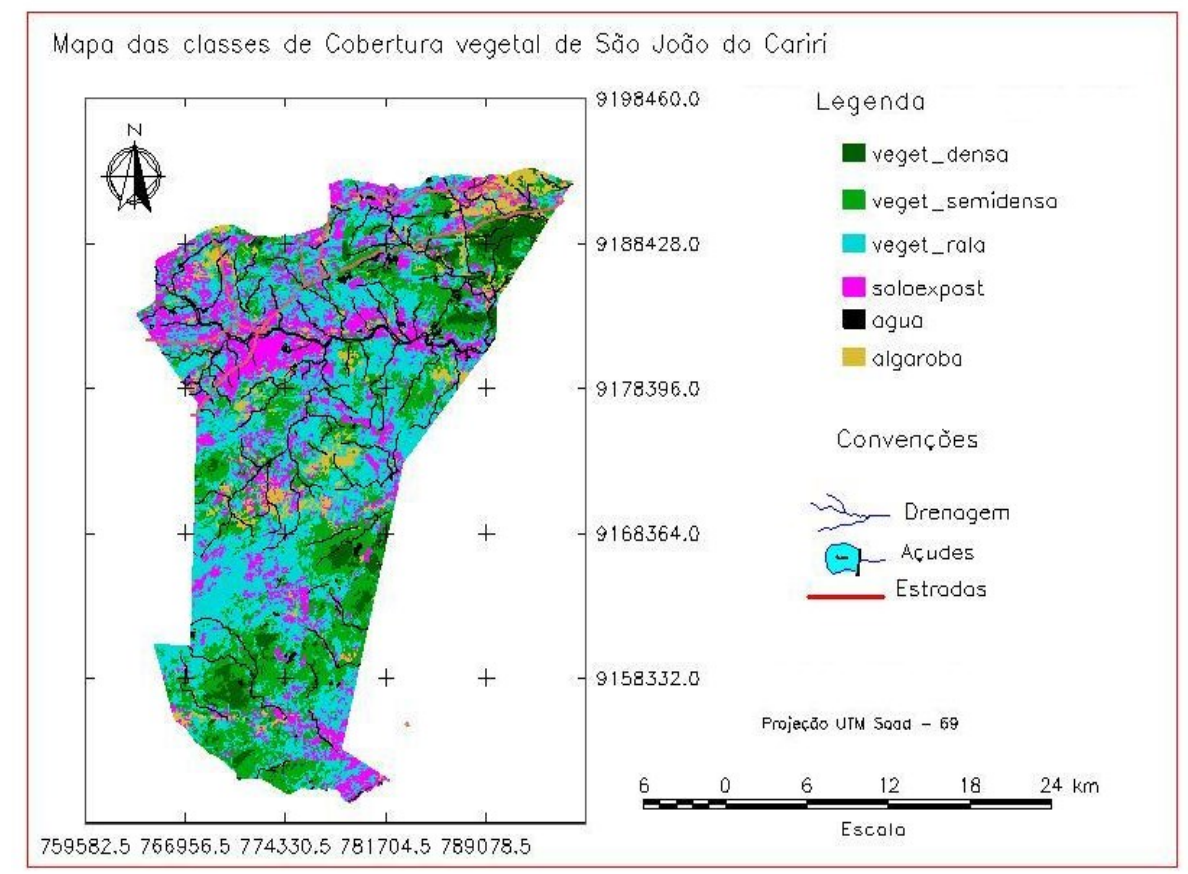

Figura 7. Mapa das classes da cobertura vegetal do ano de 1996 para São João do Cariri - PB, obtidas a partir das imagens CBRS, cartas cartográficas e trabalho de campo.

Quando se passa a analisar a dinâmica da vegetação entre os anos de 1996 e 2007, observa-se um comportamento de modo díspar da década anterior, isto é, vê-se uma melhora nos índices das diversas classes de cobertura vegetal, e ,de modo acentuado, da espécie exótica Algaroba.

Os resultados mostraram que a classe vegetação densa teve uma recomposição surpreendente, acendendo de $6,1 \%$ para $9,1 \%$, superando os índices observados em 1987. Com relação à classe vegetação semidensa, nessa última década estudada, esta se manteve praticamente estável, com uma pequena evolução de $25,8 \%$ para $30,7 \%$, índice um pouco inferior ao que ocorria no final da década de 1980. Já o processo de expansão da classe de cobertura da Algaroba pode ser observado na Tabela 3.

No que concerne à classe solo exposto, no decorrer do período estudado, a pequena oscilação ocorrida, para mais ou para menos, sempre esteve entre $17 \%$ e $18 \%$, mantendo-se praticamente estável. 


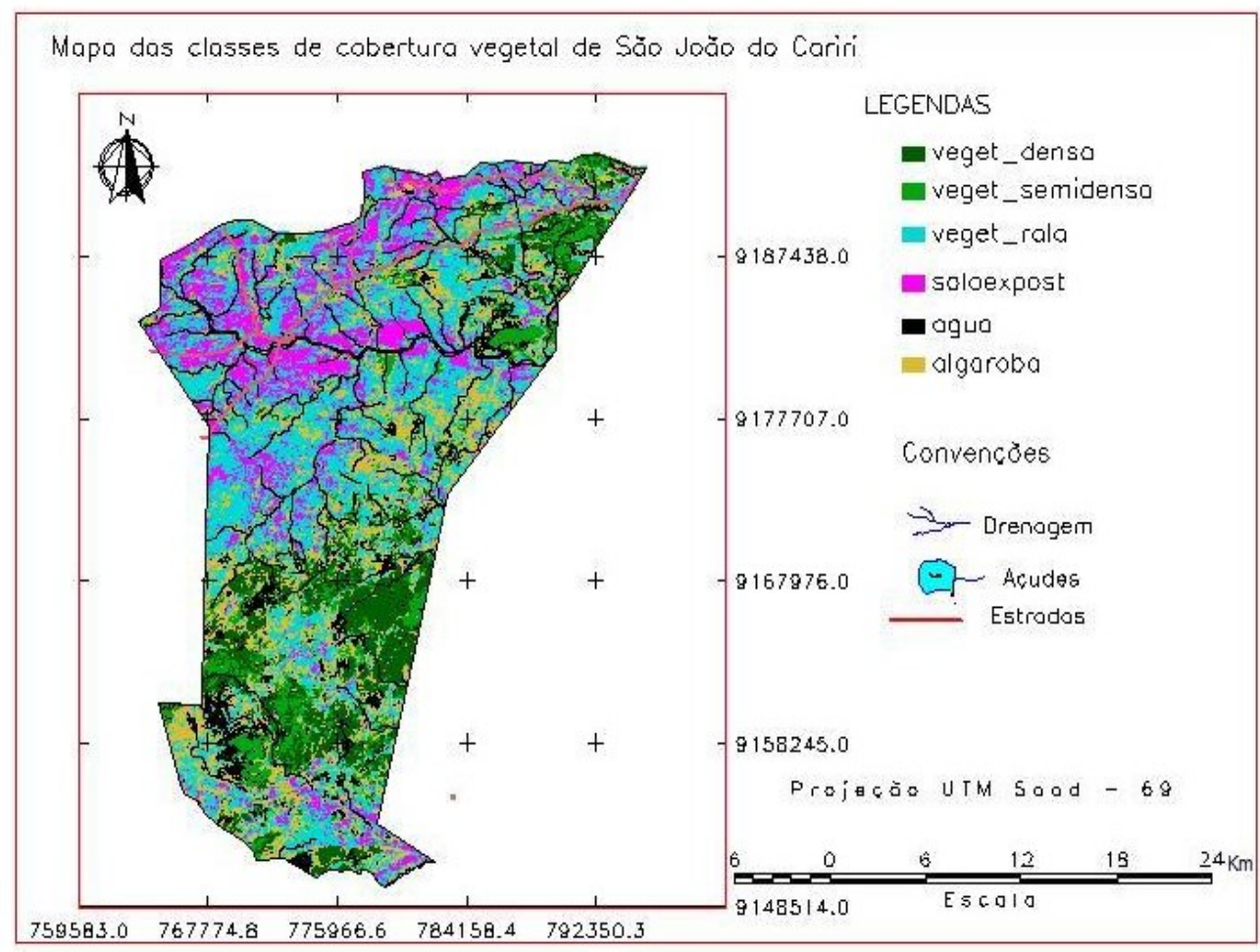

Figura 8. Mapa das classes da cobertura vegetal do ano de 2007 para São João do Cariri - PB, obtidas a partir das imagens CBRS, cartas cartográficas e trabalho de campo.

Tabela 3. Áreas correspondentes às classes de vegetação $\left(\mathrm{Km}^{2}\right)$ para os anos de 1987, 1996 e 2007. Entre parênteses encontram-se as porcentagens relativas à área total do município.

\begin{tabular}{c|ccc}
\hline Classes & 1987 & 1996 & 2007 \\
\hline Vegetação densa & $60,3(8,6 \%)$ & $42,5(6,1 \%)$ & $64,0(9,1 \%)$ \\
Vegetação semi- & $235,0(33,5 \%)$ & $181,0(25,8 \%)$ & 215,0 \\
densa & & & $(30,7 \%)$ \\
Vegetação rala & $215,0(30,7 \%)$ & $293,5(41,9 \%)$ & $210,0(30 \%)$ \\
Solo exposto & $120,0(17,1 \%)$ & $132,5(18,9 \%)$ & 122,0 \\
& & & $(17,4 \%)$ \\
Água & $1,5(0,2 \%)$ & $1,5(0,2 \%)$ & $3,2(0,5 \%)$ \\
Algaroba & $52,5(7,5 \%)$ & $48,5(6,9 \%)$ & $85,0(12,1 \%)$ \\
Área não classificada & $16,3(2,3 \%)$ & $1,1(0,2 \%)$ & $1,4(0,2 \%)$ \\
\hline
\end{tabular}


Por sua vez, a classe de cobertura vegetal constituída pela Algaroba, embora tenha sofrido algum controle, seja por parte dos produtores com maior nível de esclarecimento, erradicando-a das áreas de plantio, seja pela necessidade de a população mais necessitada em busca de alternativa de renda, o fato é que a espécie continua a ocupar extensas áreas de solos férteis, inviabilizando qualquer outra atividade consorciada, como mostra a Figura 9. Como mostrado nas imagens de satélite, essas áreas são potencialmente agrícolas, tanto as margens dos rios como os córregos que cortam o município.

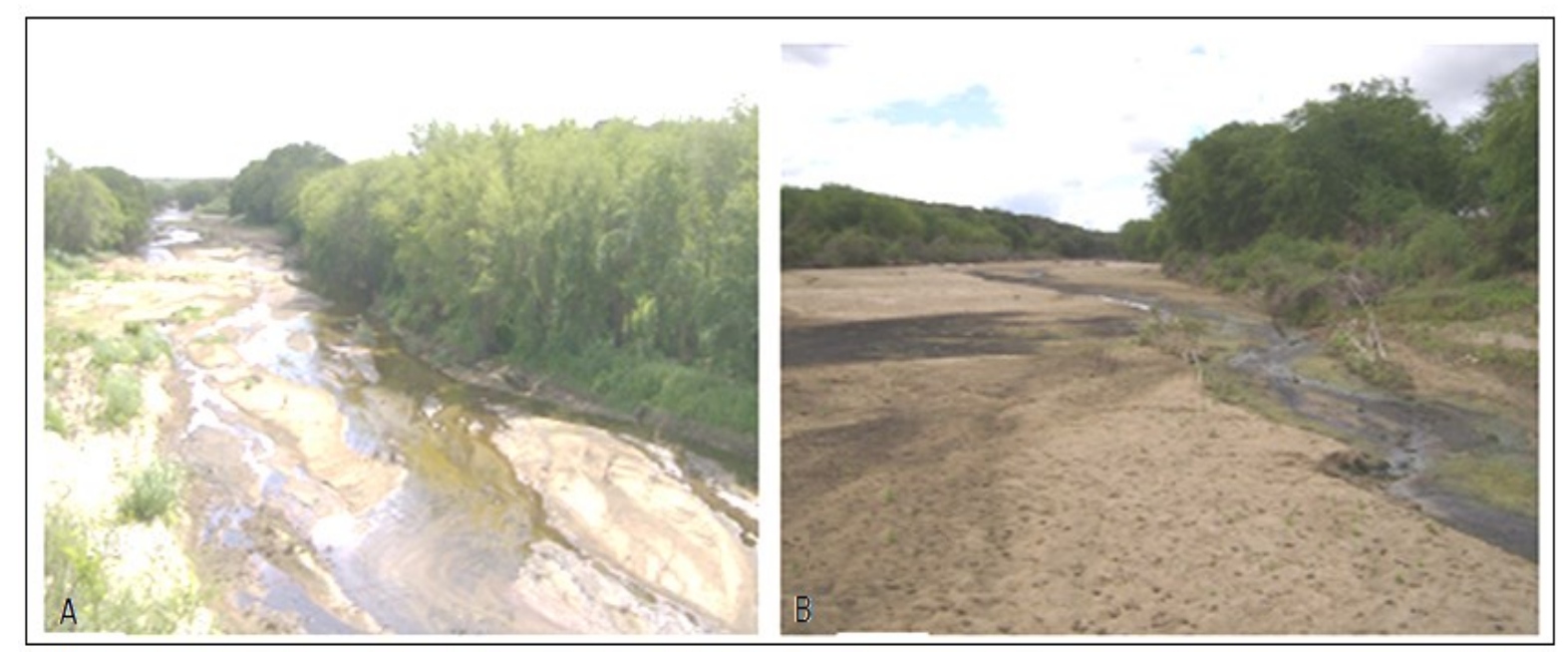

Figura 9. Infestação da Algaroba nas áreas marginais aos rios [Serra Branca (A) e Taperoá (B)] dentro da área de estudo. Estes locais são comumente utilizados para plantio de culturas de subsistência.

Além disso, como agravante nesse processo da infestação da Algaroba, existe um aspecto que deve ser ressaltado: a redução das áreas agrícolas localizadas às margens dos rios, ocasionada pela erosão lateral provocada por intensas enxurradas, favorecida pela ausência de mata ciliar. O problema da ausência de vegetação nativa ao longo dos rios traduz de forma inequívoca dois conflitos de efetiva relevância. O primeiro, de cunho ambiental, haja vista a precariedade da algaroba na proteção à cobertura do solo. O segundo, de caráter legal, pois fere frontalmente o que determina a legislação pertinente, uma vez que não se insere nos parâmetros determinados pelo Código Florestal 
Brasileiro, Lei n $n^{\circ}$ 4771/65 Artigo $2^{\circ}$, que considera, como Área de Preservação Permanente, as florestas e demais formas de vegetação natural, situadas ao longo dos rios ou de outro qualquer curso d'água. Como consequência tem-se uma acentuada perda de solo e a reboque desse processo um intenso assoreamento dos rios da área, como mostra a Figura 10.

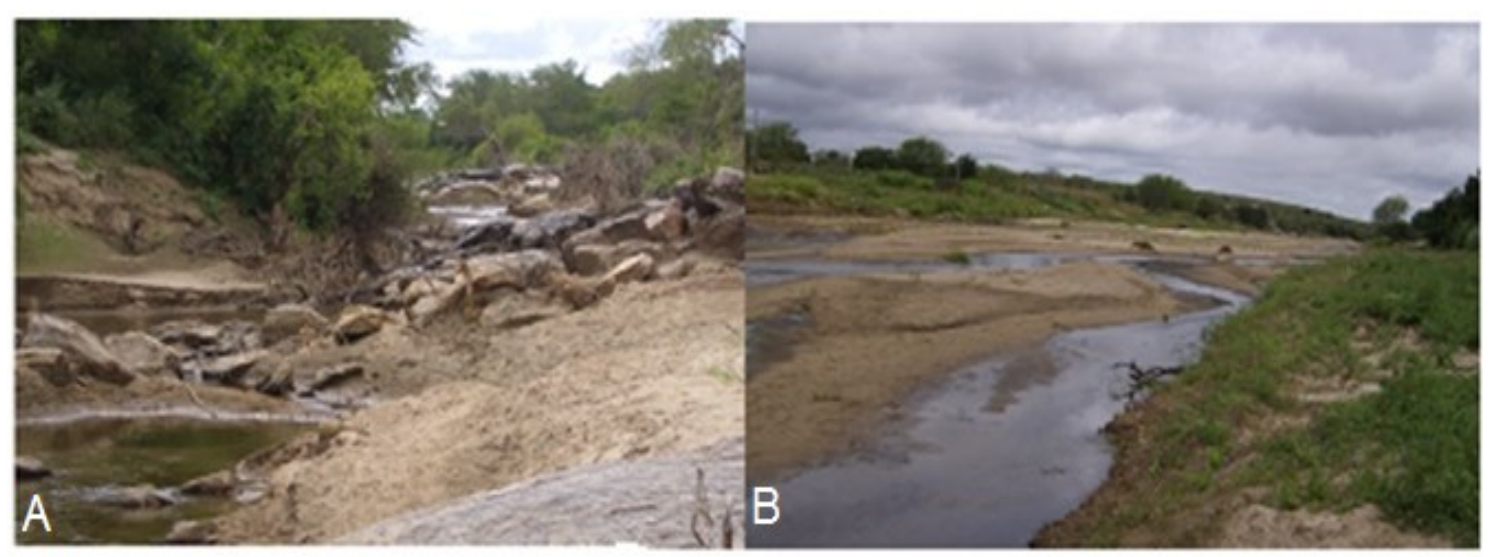

Figura 10. Processo de erosão lateral no Rio Taperoá - PB, ação atribuída ao regime de enxurradas, mas potencializada pela presença da algaroba, substituindo a mata ciliar nativa.

Com este estudo, testemunhou-se o descumprimento às determinações legais, bem como a falta de um programa que esclareça aos produtores rurais a importância da conservação da mata ciliar nativa para a manutenção da boa qualidade da água e a proteção aos solos, evitando processos deteriorantes como assoreamento dos cursos e corpos d'água.

Para se ter uma idéia a respeito do efeito da erosão lateral do Rio Taperoá, decorrente da falta de vegetação nativa em suas margens ao longo do município de São João do Cariri, a largura de sua calha mede hoje, aproximadamente, cem metros de extensão, enquanto que, há vinte anos no mesmo trecho, esta extensão não atingia setenta metros, conforme dados comparados das imagens analisadas. Logo, percebe-se que a Algaroba não dispõe de nenhum atributo para suprir a ausência da vegetação nativa ao longo dos rios da área mencionada, contrariando a lógica dos que a preconizaram como solução para a cobertura vegetal da Caatinga. 
Pelos resultados obtidos nesta pesquisa, pode-se constatar que a flutuação no comportamento da cobertura vegetal não é decorrente apenas do quadro natural, mas depende também das condições socioeconômicas da parcela mais pobre da população. Outro aspecto relevante e pouco comentado é o fato de como a espécie se prolifera nas áreas de solos profundos e, dado ao seu sistema radicular, não protege o solo das margens, favorecendo a erosão fluvial lateral, como demonstrado na Figura 10. Assim, o processo de invasão da Algaroba no Semiárido pode ser considerado grave, mas não irreversível, uma vez que, aspectos como a solução sua proliferação, ou seu manejo adequado ainda são pouco estudados.

Querendo ou não, a espécie já está inserida à região e, ainda, às praticas da população que utilizam suas vagens para alimentação animal, sua madeira como lenha e para cercas já fazem parte da realidade local. Com estudos mais aprofundados, talvez seja possível fazer o manejo adequado da Algaroba para minimizar seus efeitos negativos sob a vegetação autóctone, sem perder seu potencial produtivo.

\section{CONCLUSÕES}

Como resultado do uso do solo, consorciado com as condições climáticas presentes na área de estudo, pode-se concluir que os recursos vegetais se constituem em um fator condicionante e, ao mesmo tempo, elemento de equilíbrio, tanto no que se refere à prevenção de processos erosivos, aumentando ou diminuindo os níveis de proteção, quanto do ponto de vista socioeconômico, pois representa uma saída vital às populações em épocas secas, por meio da venda de produtos, tais como: lenha, carvão vegetal, estacas para cerca, etc.

O processo de ocupação desordenado e as políticas públicas ineficazes têm causado a redução drástica da vegetação arbóreo-arbustiva, fazendo com que se busquem alternativas econômicas como forma de suprir tais necessidades. 
A introdução da Algaroba, apontada a priori, como saída para a crônica escassez de biomassa e forragem na Caatinga, em que pese ter atendido em parte tais requisitos, trouxe mais problemas do que solução, na medida em que faltou conhecimento técnico que possibilitasse seu manejo adequado. Como resultado dessa omissão, pode-se constatar que grande parte das áreas de solos úmidos às margens dos rios e açudes encontra-se infestada pela espécie, acarretando problemas não apenas ambiental ao povoar o espaço da mata ciliar nativa, mas também socioeconômico, já que representa um obstáculo à produção agrícola e ocupa as poucas áreas propícias ao plantio das culturas de subsistência.

Contudo, de acordo com o que este estudo constatou, existem variadas opiniões a respeito dos benefícios e malefícios relacionadas à população de Algaroba nas áreas aludidas. Para alguns, a espécie é indispensável como fornecedora de forragem e biomassa e, para outros, a maioria, representa um problema de consideráveis proporções, classificada inclusive como praga, devido à dificuldade em extingui-la. No entanto, em um ponto existe consenso: a necessidade premente de se manejar a espécie, partindo-se de um conhecimento técnico aprofundado embasado em pesquisas, com o intuito de que se possa aproveitar seu potencial (que não é desprezível) e reduzir sua influência.

\section{REFERÊNCIAS BIBLIOGRÁFICAS}

AB' SABER, A. N. O domínio morfoclimático das Caatingas brasileiras. In: Geomorfologia. São Paulo: USP - Instituto de Geografia, 1974. 2003.

Os domínios de natureza no Brasil. São Paulo: Ateliê editorial,

ANDRADE, M. C. de. A terra e o homem no Nordeste. 5. ed. São Paulo: Atlas, 1986.

ANDRADE, L. A.; BARBOSA, M. R. V.; LEITE, U. T.; PEREIRA, I. M. Análise da cobertura de duas fitofisionomias de caatinga, com diferentes históricos de uso, no município de São João do Cariri, estado da Paraíba. Revista Cerne, Lavras - MG, v.11, n.3, p.53-262, 2005. 
ANDRADE, L. A. de.; PEGADO, C. M. A.; PEREIRA, I. M. Efeitos da invasão biológica de algaroba (Prosopis juliflora [Sw] DC) sobre a composição e a estrutura do estrato arbustivo-arbóreo da caatinga no Município de Monteiro, PB, Brasil. Revista Acta Botânica Brasilica, São Paulo, v. 20, n. 4, 2006.

ANJOS, C. E. dos; VENEZIANI, P. Metodologia de interpretação de dados de sensoriamento remoto e aplicações em geologia. São José dos Campos: INPE, 1982.

BRASIL. Secretaria de Desenvolvimento Territorial SDT/MDA - Estudo Propositivo para Dinamização Econômica do Território do Cariri (Versão Preliminar), 2005.

CPTEC/INPE, Centro de Previsão de Tempo e Estudos Climáticos/ Instituto de Pesquisas Espaciais. El Niño e La Niña. Disponível em: $<w w w . e n o s . c p t e c . i n p e . b r>$. Acesso em Junho/2010.

DUARTE, J. J. A nova paisagem do semi-árido no contexto da modernização: o caso da Algaroba. Revista da Adufpb, João Pessoa, v. 1, n. 1, p. 17-32, 2000.

GAN, M. A. Um estudo observacional sobre as baixas frias da alta troposfera nas latitudes subtropicais do Atlântico Sul e leste do Brasil. 1983. Dissertação (Mestrado em Meteorologia). Instituto Nacional de Pesquisas Espaciais, São José do Campos.

IBGE, Instituto Brasileiro de Geografia e Estatística - Delimitação de limites municipais. Base operacional, PB. Rio de Janeiro: Edição Revisada, 2006.

Disponivel em <http://www.ibge.gov.br/censo2010/primeiros dados divulgados/index.php?uf= 25> Acesso em abril de 2011.

INPE, Instituto de Pesquisas Espaciais. Downloads de imagens de satélite. São José dos Campos - SP, 2008. Disponível em <www.dgi.inpe.br> Acesso em março de 2008.

JOFILLY, I. Notas Sobre a Parahiba. Livro I. Rio de Janeiro: Thesaurus Editora, 1892.

KOUSKY, V. E. Diurnal rainfall in Northeast Brasil. Monthly Weather Review. Washington DC, v. 108, n. 4, p. 488 - 498, 1980.

KOUSKY, V. E.; CAVALCANTI, I. F. El Niño/Southern Oscillation events: characteristics, evolution in precipitation anomalies. Ciência e Cultura. Campinas - SP, v. 36, n. 10, p. 1888 - 1899, 1988.

LINS e SILVA, A. C. B. Characteristics of Prosopis juliflora invasion of semi-arid habitats in Norteast Brazil. 1997. 76 f. Thesis (M.Sc.) University of Durham, Durham.

MELO, A. T. de; RODRIGUEZ, J. L. Mapa do Estado da Paraíba. Paraíba: desenvolvimento econômico e a questão ambiental. João Pessoa: Grafset, 2004. 
MOLION, L. C. B.; OLIVEIRA, S. Uma revisão da dinâmica das chuvas no Nordeste Brasileiro. Revista Brasileira de Meteorologia. Rio de Janeiro, v. 17, n 1, p. 1-10, 2002.

NASCIMENTO, C. E. de S. Comportamento invasor da Algarobeira, Prosopis juliflora (sw) dc. nas planícies aluviais da Caatinga. 2008. Tese (Doutorado em ) UFPE, Recife, Pernambuco.

OLIVEIRA, F. X. de. Impactos da invasão da Algaroba - Prosopis juliflora (sw.) DC. -sobre o componente arbustivo-arbóreo da caatinga nas microrregióes do Curimataú e do Seridó nos estados da Paraíba e do Rio Grande do Norte. 2006. Dissertação (Mestrado em Agronomia). Universidade Federal da Paraíba, Areia - PB.

PEREIRA, R. A. Impactos ambientais decorrentes das condições antroponaturais no município de São João do Cariri-PB. 2008. Dissertação (Mestrado em Recursos Naturais). Universidade Federal de Campina Grande, Campina Grande - PB.

PEREIRA, R. A; MELO, J. A. B.; SILVA, M. T.; ALMEIDA, N. V. Análise do comportamento espectral da cobertura vegetal de uma área de caatinga, após sucessivas estiagens. Caminhos de Geografia, Uberlândia - MG, v. 10, n. 29, p. $88-96,2009$.

REBOUÇAS, A. Água e desenvolvimento rural. Estudos Avançados, São Paulo, v. 15, n. 43, 2001.

SUDENE. Cartas topográficas na escala 1:100000: Juazeirinho (SB.24-Z-D-II); Boqueirão (SB.24-Z-D-III); Sumé (SB.24-Z-D-V). (Ano-base: 1972). Disponível em: <www.pb.gov.br/sudema>. Acesso em fevereiro de 2008.

TELES, M. M. F.; ANDRADE, A. P.; ROSA, P. R. O. Delimitação espacial da vegetação do município de São João do Cariri - PB. Revista Geografia, Recife - PE, v. 15, n. 1, 2006.

UVO, C. R. B., NOBRE, C. A., CITEAU, J. Análise da Posição da Zona de Convergência Intertropical (ZCIT) no Atlântico Equatorial e sua Relação com a Precipitação no Nordeste do Brasil. In: CONGRESSO BRASILEIRO DE METEOROLOGIA, 11, 1988, Rio de Janeiro (RJ): p. 323 - 327.

VILLA, Marco Antonio. Vida e morte no Sertão: história das secas no Nordeste nos Séculos IX e XX. 1. Ed. São Paulo: Ática, 2000.

VILAR, F. C. R. Impactos da invasão da algaroba [Prosopis juliflora (Sw.) DC.] sobre estrato herbáceo da caatinga: florística, fitossociologia e citogenética. 2006. Tese (Doutorado em Agronomia). Universidade Federal da Paraíba, Areia - PB.

YAMAZAKI, Y, RAO, V. B. Tropical Cloudiness over the South Ocean. Journal of the Meteorological Society, Reading, v. 55, n. 2, p. $205-207,1977$.

Recebido em 04/04/2012.

Aceito em 27/03/2013. 